\title{
Socio-Economic Problems of Migrant Workers: A Micro-Level Study of Migrated Unskilled Labour to Hyderabad City
}

\author{
Preetham Surya .V \\ M.Phil. Regional Studies, University of Hyderabad
}

\begin{abstract}
My research work is on the micro-level study of construction workers where I am trying to understand the micro level aspects of their migrant society. As the name suggests this is the smallest of the levels of society. Micro level groupings are more intimate societies that many humans will automatically identify with first. However, the complexity of this small group is that within the larger levels of society there are still smaller micro levels that make them up. The micro level deals with the daily actions and interactions of people in society. It examines the social roles that we take on within society as well as how we react to society and understand it. At this more intimate level the focus is on how people think within society opposed to their behaviour. Micro level study of society hones in on the smallest elements that create the idea of what a society is, the norms and behaviours that make it recognizable as a its own society. Rituals, socialization, segregation of activities and sanctions are all indicators as to how one should interact within a society. They are the guidelines that mentally tip us off as to the type of micro level society we are in.
\end{abstract}

Keywords: migration, unskilled, labour, society, urban, rural, construction, workers, Hyderabad

\section{Introduction}

\subsection{Problem}

Why migration is considered as one of the major problems for the unorganized labourers?

In brief my research topic migration of unskilled labour is studied in micro-level which means to understand the migrant society.A large number of migrants driven by drought, starvation and often, social persecution migrate to India's urban centers with no other aim but to find a means of livelihood and find their way into the construction sector. The construction industry has a long tradition of employing migrant labour. In the rural areas, self-employment is the predominant activity for both male and female migrant workers followed by casual work. This labour body is essentially mobile and floats into the city where it is easy to exploit. The construction sector, with its huge demand for unskilled labour, ultimately provides employment to a majority of this migrant work force. The logic of the construction industry is one of sub-contracting and decentralization. In this framework, unskilled and semiskilled workers become easy to exploit. The most exploited in this industry are the migrant workers who migrate from rural areas to feed the demand for labour. Employers and contractors display a commensurate preference for migrant labour because it is easier to exploit and less vociferous about its rights. Millions of men and women migrate from rural to urban areas every year. Only a small percentage knows what they want to do and how they are going to live in a new place.

\subsection{Purpose}

The purpose of this study was to provide a micro-level point of view analysis of the migrant society and their livelihood. Historically, these migrants are being exploited by the contractors for work and also denied their rights. In this paper I would like to bring out a case study of Hyderabad construction workers, where after years of exploitation these migrant people have become so aware of the conditions, prevail in the cities. This paper also tells about how these vulnerable smaller societies make transitional arrangements with the construction companies before they enter in to the city and also how culturally different migrants come and stay together in a place and interact in their daily activities.

\section{Background}

\subsection{Conditions of migrant workers in India}

Migrants form the largest part of India's vast unorganized work sector. Their entry into the labour markets is marked with several endemic disadvantages. Devoid of critical skills, information and bargaining power, migrant workers often get caught in exploitative labour arrangements that forces them to work in low-end, low-value, hazardous work. Lack of identity and legal protection accentuates this problem. The hardships of migrant workers are especially magnified when state boundaries are crossed and the distance between the "source" and "destination" increases. Migrants can also become easy victims of identity politics and parochialism.

Despite the vast numbers of migrant workers, the policies of the Indian state have largely failed in providing any form of legal or social protection to this vulnerable group. In a continuous state of drift, migrants are left out of the scope of state provisions at both ends - the "source" and the "destination". The urban labour markets treat them with opportunistic indifference extracting hard labour but denying basic entitlements such as decent shelter, fair priced food, subsidized healthcare facilities or training and education. They are also usually out of bounds of government and civil society initiatives, both because of being "invisible" and for their inability to carry entitlements along as they move. 


\section{International Journal of Science and Research (IJSR) \\ ISSN (Online): 2319-7064}

Index Copernicus Value (2015): 78.96 | Impact Factor (2015): 6.391

There is one legislation known as Inter-State Migrant Workers Act, 1979 which aims to safeguard migrants. However, it is obsolete and is hardly enforced anywhere. A serious constraint in framing an effective policy is the lack of credible data on incidence of seasonal migration. Census and NSS that have a significant impact on policy making are unable to capture seasonal and circular migration. Migrants may also be missed out in BPL Surveys. Above all, they are unable to participate in the formal electoral system and are denied a fundamental citizenship right - their right to vote.

Economic growth in India today hinges on mobility of labour. The contribution of migrant workers to national income is enormous but there is little done in return for their security and well-being. There is an imminent need for solutions to transform migration into a more dignified and rewarding opportunity. Without this, making growth inclusive or the very least, sustainable, will remain a very distant dream.

The construction industry is one of India's largest employers. Thousands of construction workers who have to build the new apartments and offices live in squalor in roadside tents that sit uneasily among the city's new glamour.They are migrants from the decimated agricultural sector; escaping from poverty and disease at home they are sucked into a labour economy that is characterized by exploitative labour practices, unsafe working environments, inhuman living conditions with little access to basic amenities and almost complete social exclusion. They have little or no work security and their income varies according to seasonal or other fluctuations in the demand for labour.Migrant workers move from project to project, labour camp to labour camp. There is no sense of a house or a room. Even within a camp, there is no specific place allocated since they work on shifts. All the family is working on the construction site, also women and children.

\section{Theoretical support}

As I am concerned with migration, I will briefly discuss how emigration is studied based on the migration theories that we know till now. Lee model of migration (1966), Gravity model and Chain migration theories are strong bases for my research topic.

Lee's Push-Pull Model (1940s) is an attempt to explain the patterns of migration and decision of migration (individual or family) which depends on:

- Characteristics of the origins

- Characteristics of the destinations

- Nature of intervening obstacles (e.g. cost. Borders, etc...)

- Nature of people

The push and pull factors of the migrant construction workers are explained in the subsequent chapters of this dissertation.

The gravity model of migration is a model in urban geography derived from Newton's law of gravity, and used to predict the degree of interaction between two places. The gravity model can be used to estimate:

- Migration between two areas
- The number of people likely to use one central place

- Uses population origins and destinations as measures of diversity

- Attraction may be economic; obstacle may not be distance

The gravity model can also be used to determine the sphere of influence of each central place by estimating where the breaking point between the two settlements will be. An example of this is the point at which customers find it preferable, because of distance, time and expense considerations, to travel to one center rather than the other.

Chain migration model can be defined as a "movement in which prospective migrants learn of opportunities, are provided with transportation and have initial accommodation and employment arranged by means of primary social relationships with previous migrants." It explains the opportunities localized within cities which are:

- Migrants use established transport routes or streams

- flow of information about a destination back to origins

- Follows migrants path therefore $\rightarrow \uparrow$ knowledge of destination ( $\downarrow$ obstacle $\uparrow$ attractiveness)

Chain migration creates social capital among people to whom the migrant is related, thereby raising the odds of their migration. Social capital is the tool by which chain migration occurs. It the context of migration, social capital refers to relationships forms of knowledge and skills that advance one's potential migration.

\section{Research Methodology}

Both quantitative and qualitative study has been done to collect data from the migrants. The primary data collected for this research is based on the participation observation method, personal interview method (open ended questions) and questionnaire method. Secondary data involved a socioeconomic survey which helped to understand the nature of migration and demographic status of the migrants.

\section{Sample}

The data for this study has been collected from the work site of Hyderabad central university at Gachibowli, Hyderabad. A cluster sampling method was adopted and covered nearly 30 households. Of these 30 households, 16 households comprise Telugu speaking people from Andhra Pradesh state and the remaining 14 households consist of Hindi, Santali, Chhattisgarhi, Bengali and Odiya speaking people of different states.

\section{Case study}

The form of migrations observed are inter-state migration and intra-state migration which is also called as emigration. Internal migration is now seen as a major mechanism for the redistribution of resources from the richer to poorer localities and a vital means of raising the incomes of poor. Migration is a politically controlled process, but nowadays the source country/state government might encourage the emigration of the low-skilled in order to maximize remittances. In the course of this, the low-skilled might enrich their capacities through training and work experience, at which stage the source country/state might want to 


\section{International Journal of Science and Research (IJSR) \\ ISSN (Online): 2319-7064}

Index Copernicus Value (2015): 78.96 | Impact Factor (2015): 6.391

encourage the worker to return with those skills and with the knowledge of market contacts. To understand the migration among the people who are from different cultures, languages and social structure and have come to stay in a place with a new environment is a rather difficult task. Certain norms and behaviours are common among the migrant people which I had understood after studying the available literature on migration. Norms and behaviours are nothing but the profile of the migrants of which can be studied by conducting socio-economic survey.

\section{Rural to Urban Migration}

Employers prefer to hire migrant labour, as they are considered to be cheaper and more docile than local labour. Consequently, labourers need to migrate in search of jobs, which they are denied in their native region. This perpetuates a vicious cycle of migration. Also, there often seems to be an inherent specialization among labourers according to their place of origin, resulting in region and task specific movements. The Nagarjuna construction Company has assigned the contractors for work force .i.e. in need of the workers and these contractors move to different places/regions. The old workers who are working in the company give some information to the mestri's(contractors) about their friends/ relatives in their home town who are in need of work. Most of the migrant construction workers are rural to urban and very few moved from urban to urbanbecause they are in constant touch with their construction company for many years. Suchmigrants are from Andhra Pradeshof different districts ofEast Godavari, srikakulam, Guntur and Prakasam(Ongole), from where the highest number of migrants is observed. Inter-state migration has been mainly from the states of Jharkhand (lohardaga, palamau); Odisha (dharamgarh, keonjhar), Chhattisgarh (Rajnandagoan, durg), Uttar Pradesh (kusinagr) and West Bengal (bankura). Here the gravitation model of migration is observed because many number of the workers of same locality likely to move to one central place because of getting good income in the Hyderabad city. Many them had said that distance is not an obstacle for them and these workers follow the chain migration as said via social capital i.e. maintaining constant contacts with their friends and helping them in providing work in the same company through contractors.In order to protect their rights, they claim their rights by making obligations to the companies and making transitional agreements for their security and protection are thoroughly checked by the educated workers before migrating to the city. They are:

1) The company should provide them residence at the site area.

2) It should provide insurance to every unskilled worker.

3) If any worker meets with an accident during the course of his work at the site, the company should bear all the hospital expenses and he should be given the remaining amount of money for his work. They should be provided with food and drinking water facilities.

To them distance is not an obstacle because the transport is being provided by the company itself and they also provide every worker insurance which health and other basic services. They are also given money by the company to get rid off with any debts/credits which they have to pay at their home town. In doing so the worker gain trust on the company and he also suggest his friends or relatives to work for the company. More work force available for the company, the higher the name and reputation to the company.Along with education, through observation of different factors that are involved in construction field, they are able to protect themselves and are united during the times of disturbances that are created by the contractors.

Local conditions: Most of the migrated workers are married and have moved along with their families. Most of the Telugu speaking people, especially males, involved in the unskilled work, while the females are mainly involved in the household activities. However, among the migrants from other states, male workers are involved in both unskilled and skilled work such as carpenters, barbenders, tillers and painters etc.and female workers are involved in unskilled work and the household activities. The residential area of the migrants is very near construction siteand area is provided with moderate water facilities, electricity and the houses are made of steel material.After joining in the work the company provides them with insurance, housing, health and transport facilities etc. and make sure that they do not leave the company. Based on the occupational pattern of both male and female migrants, before and after migration and their experience in work, the contractors try to segregate the activities of work among the workers based on the availability of labour force. As a result, occupational choice is more or less supply driven, though from the macro point of view, keeping the entire city in perspective, the equilibrium choice of occupation would be the outcome of both demand and supply side factors

\section{Age at Migration}

Age is one of the important factors to understand migration because when a family together migrates to a destination, the children whether of tender age or adultsare greatly influenced by the migration. They come to know why their parents are migrating and what the purpose to migrate is. The reverse is also true, for, influenced by them slowly the adults start working in the construction sites and move here and there to earn. Unmarried male workers do stay near the site but reside in a single room together, away from the family households. Many of them come inthe age category 20-25years. Out of the 30 households surveyed, taking an average, the age of respondents are in the age group 26-30 are maximum in number. They feel that it is the good age to work, to earn and gain experience and to lead their family lives. Some of them educate their children in their place of origin leaving with their grandparents understanding that their situation in the place to which they have migrated is worse. But some workers feel that together family is an economic unit, where husband, wife and children stay together and work for their livelihood. Unfortunately, the children who grow up watching them often end up in the same field of work, because some of the parents are unable to educate their children due to the problems they have at the place of origin and at the destination too. This situation happens with the workers due to their long duration stay since migration. Generally these migrant workers get married very early, often between the 


\section{International Journal of Science and Research (IJSR) \\ ISSN (Online): 2319-7064}

Index Copernicus Value (2015): 78.96 | Impact Factor (2015): 6.391

ages of 18 and 25 . The reason behind this is the responsibility they feel towards their family and they start earning in the tender age.

\section{Language:}

To these workers language is not a barrier because they are instinct to earn more money and improve their livelihoods at place of origins and destinations too. Hindi, Telugu Bhojpuri, Chhattisgarhi, Santali, Bengali and Odiya are the languages spoken. Even though language is not a barrier, here the migrant communities are considered as Hindi and Telugu. They frequently talk to each other because either of them knows Telugu or Hindi.As observed earlier, the Telugu speaking workers of Andhra Pradesh are separated from the other northern state construction workers seldom talk to each other.Another reason is to prevent conflicts between them. The adults who are unmarried unskilled labour are given as separate house at the other side of whole construction complex.

\section{Religion and caste:}

Most of them belong to the scheduled castes and they migrated to the city due to social discrimination and the nonavailability of proper daily work in their place of origin. In order to free themselves from such lower hierarchy of status, they migrate to cities for work in a pre-planned manner through social capital i.e. maintain constant communication with their friends, relatives and co-workers who are working in the cities.The majority of the Telugu workers are Christians belonging to the Scheduled Castes (madiga) and other backward classes are Hindus. Among the other state workers, too, Christians are in the majority, while there are a few Muslims. They also belong to other backward classes OBC (sub-castes sahus, mohanty's and satnamies) and the remaining $50 \%$ respondents belong to scheduled caste SC community of sub-castes lohar, khanjar and musharcommunities. The Christians go to church on Sundays which is inside their living area. This does not create any disturbances to the other workers community. They do celebrate their respective festivals at their places without any hesitation. As said before, the language barrier creates a gap between the Hindi and Telugu speaking people, but there is also a concern among the latter that they should not be exploited by the outsiders and would like to live in harmony. These people think they are most vulnerable and isolated from the main society.

\section{Educational status of migrants}

While some construction labourer jobs have no specific educational qualifications or entry-level training, most workers start by getting a job with a contractor who provides on-the-job training. Increasingly, construction labourers find work through temporary help agencies that send labourers to construction sites for short-term work. In the work sites, they are given training in certain aspects which need manual dexterity, eye-hand coordination, good physical fitness, a good sense of balance, and an ability to work as a member of a team.Entry-level workers generally help the more experienced workers. They perform routine tasks, such as cleaning and preparing the worksite and unloading materials. When the opportunity arises, they learn how to do more difficult tasks, such as operating tools and equipment from the experienced construction trade workers. Education of the unskilled workers in my research area shows that many of them are illiterate, but when compared to females, males are a little bit educated where some of them completed secondary education level i.e. from class $6-10^{\text {th }}$. But even though many of them are uneducated they know all the types of work available for them in the cities and who can recruit them.

\section{Wages}

Broad categories of workers have already been identified earlier. It is important to remember that the amounts of wages paid to different types of works are different. The wages are different for skilled, semi-skilled and unskilled labour. To the unskilled labour, the wages are paid every week on Thursday. The company pays about Rs.1000/- per day for the skilled workers (carpenters, barbenders, masons, tillers and painters) depending upon how many hours of work they have done. They usually work during night times and there is no time limit. One of the interesting aspects found was that the contractors recruit male and female labourers in equal numbers, and the work is distributed among them equally and they are paid equally without any discrimination. The labourers such as masons, mestris are the supply-demand workers with daily wages of about Rs. 250/- . Again, this amount is paid to both male and female workers irrespective of gender. The daily wage labourers work from $9.00 \mathrm{a} . \mathrm{m}$. to $6.00 \mathrm{p} . \mathrm{m}$. The work is provided every day except Sundays, but there are no holidays for skilled labour because they keep on working for more money. The semi-skilled labour are also given a daily wage labour of Rs.275/-.

\section{Role of Women}

Certain literature tells us that females are treated as low wage workers and they are paid very less amount, but recent studies in India have reported an increasing number of young women joining the migrant flow to cities, many of them going on their own to find work in service, manufacturing and informal sectors.Due to rapid urbanization there has been large scale migration of workers into the urban areas from the rural areas. Since most of the women who migrate along with their families are unskilled, they are absorbed into the booming construction industry as unskilled labour.In rural areas, only about $1 \%$ of the total rural women workers are found to be engaged in construction work mostly provided by public works. It has been found that rural women usually shift from agriculture to construction work in case of drought but most of them revert to agriculture after the drought.

The majority of the female workers are unskilled labour and they moved together with their families.The contractors from the NagarjunaConstruction Company recruit equal number of male and female workers and they are paid equal wages without any discrimination. The company provides only work to the women who are migrated along with their families, to ensure their income earnings.This is done to reduce gender conflicts and encourage the female workers to take part in the work and improve their livelihood and it is not to ensure that more work available is for them. One of the main forces that drive women into the construction 


\section{International Journal of Science and Research (IJSR) \\ ISSN (Online): 2319-7064}

Index Copernicus Value (2015): 78.96 | Impact Factor (2015): 6.391

sector is poverty. The jobs in this sector, in fact are far more strenuous than in the manufacturing industries. They are mostly head-load workers who carry bricks, cement, sand, water, etc. from one place to another, sometimes over heights along precariously balanced wooden beams or other temporary structures. They are also involved in cleaning up, concreting and earthwork. Women help in carrying debris dug up at the excavation stage; they help in erecting of scaffolding and curing the floor and keeping it well until it sets. Women's work is considered easy, suitable for the weak, appropriate for secondary income earner and by implication fit for irregular worker.

\section{Duration of stay since migration}

The type of migration is observed as semi- permanent migration. Many of the workers have said that they do not want to go back permanently to their places of origin except occasionally during festivals during tulekadasi. They said that the company provides work to them all over the year and the money which they earned could be used in future for different purposes. Many of them have shifted along with their families and also bring their relatives with them to join in the work. It means that they have arranged a long term plan settling in the construction field and try to diversify their income.

When asked about what a 'region' means to them, the respondents generally identified it in socio-cultural and economic terms, as a region which will provide them work and help them to diversify their incomes and protect their rights. There is also an awareness of linguistic difference, as seen in the distance maintained between Telugu and Hindi workers even in the residential areas.

\section{Figures:}

\section{Lee's Push-Pull Model}

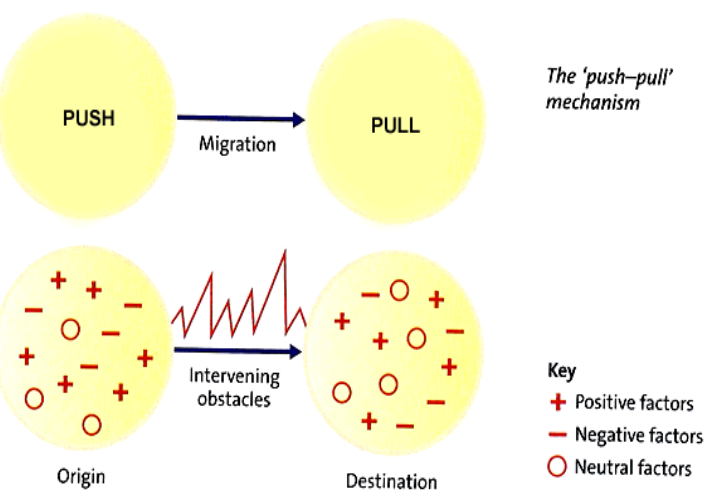

\section{Recommendations for Future Research}

It should also be pointed out here that an in-depth study has not been made of the details of the application of the terms of the agreement signed - for example, while there is mention of insurance in the agreement, details of how the premium is paid, who pays it, and what exactly it covers, have not been examined. What I found most interesting in my research is that Hindi and non-Hindi speaking migrants do not come together socially, even if they do work together. Language may not be a barrier in the workplace itself, but is maintained otherwise, with residence areas also being demarcated. Whether this can be termed a form of social behaviour common to all migrant communities is a matter that requires further research.

\section{Conclusion}

This research, conducted at a micro-level, has enabled me to understand the problems faced by the workers, as well as their efforts to overcome at least some of these problems. They are aware of exploitation, and try to make agreements to reduce the level of exploitation. On the basis of the current research, it is not possible to state whether such agreements are commonly made, only that they are a feature of the work culture with the Construction Company and workers that has been studied. It may be argued that the company gets more benefit than the workers, for as they get a guaranteed work force, they can get their projects completed on time, and therefore make their profit. But it should be pointed out that the workers also get the guarantee of a job and of subsequent employment in other projects of the same company in future as well, so that they too do not lose by allying themselves with one specific company.

\section{gravity model}

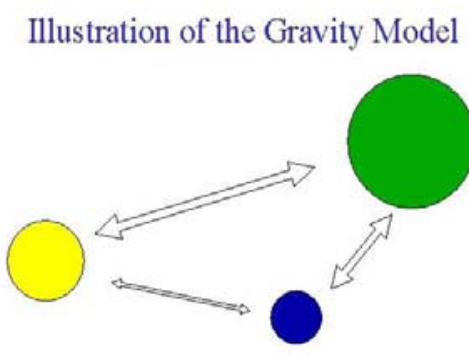

The shorter the distance between two objects, and the greater the mass of either (or both) objects, the greater the gravitational pull between the objects. 
Tables:
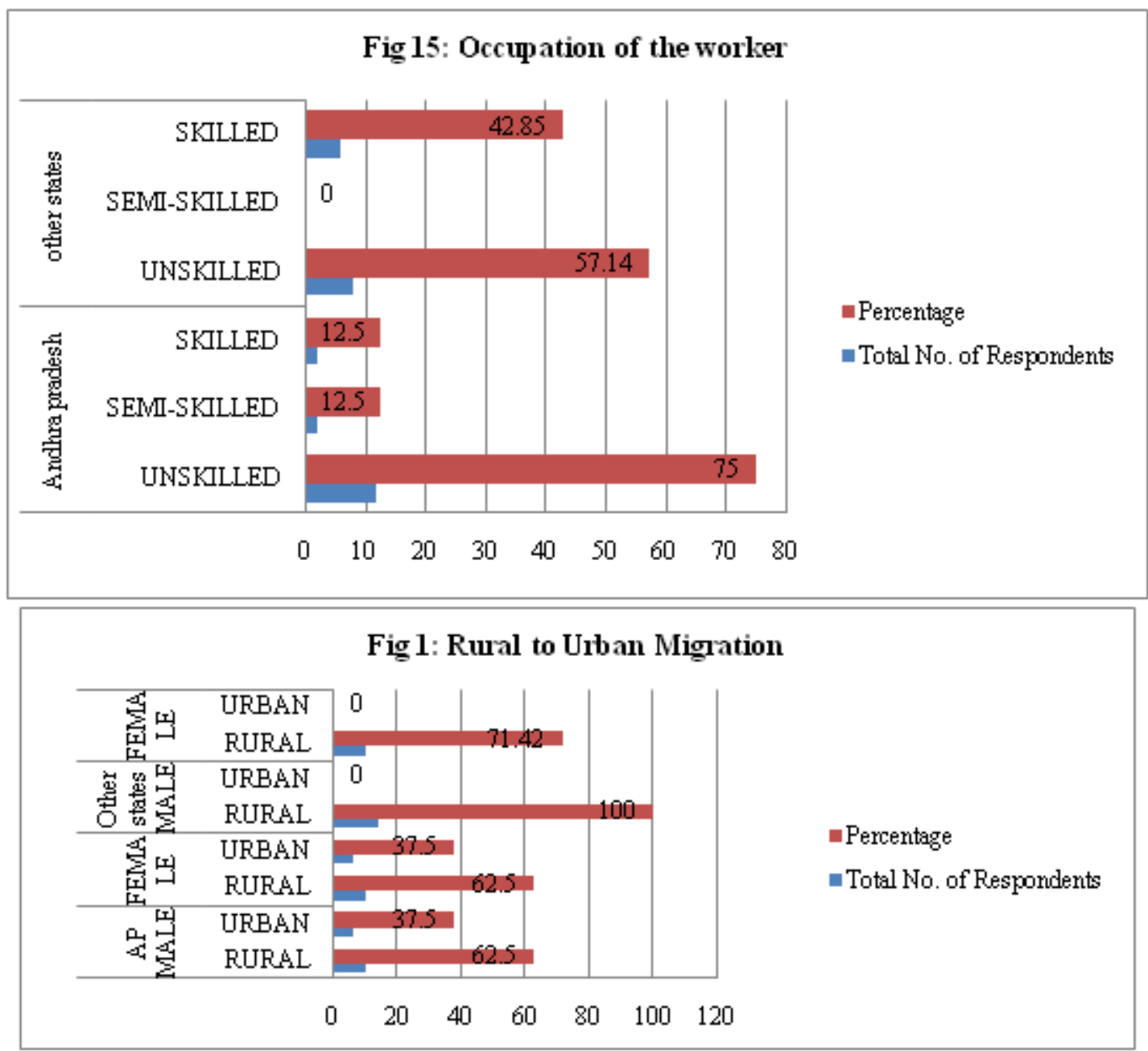

\section{References}

\section{Journals:}

[1] Amitabh Kundu and NiranjanSarangi, Migration, Employment Status and Poverty: An Analysis across Urban Centres, published in Economic and Political weekly, (pg. no.299-306), January 27, 2007.

[2] Annie Phizlackea journal, Motherhood, Marriage and Employment among American in One Way Ticket: Migration and Female Labour (1996).

[3] Arvind N Das, "Social Anthropology of Indian Labour", 20 (43) Economic \& Political Weekly. (1985).

[4] Nigel Harris, MIGRATION AND DEVELOPMENT published in Economic and Political weekly (EPW), (pg. no.4591-4595), October 22, 2005.

[5] Nigel Harris, MIGRATION OF LABOUR: Constructing Transitional Arrangements, published in Economic and Political weekly, (pg. no: 4464-4470), October 18, 2003.

[6] S. Sundari,Migration as a Livelihood Strategy: A Gender Perspective, Published in Economic and Political Weekly, (pg. no.2295-2303)May 28- June 4, 2005.

[7] V Anand, "Advocating for the Rights of the construction workers: Nirman's Experience"'59(3), The Indian Journal of Social Work, 847, (July 1998).
[8] Xiang Biao, TOWARDS AN EMIGRATION STUDY: A South Perspective, published in Economic and Political weekly, (pg. no. 3798-3803), August 21, 2004.

Books:

[9] Billsborrow R.E., T.M. McDevitt, S. Kassoudji and R. Fuller, "The Impact ofOrigin Community Characteristics on Rural-urban Out-migration in a Developing Country" Demography, vol. 24(2), 191210, (1987).

[10] J Seabrook, Victims of Development (Verso, London, 1993).

[11] Khandewale, S.V and Chorghade, S.V- Migration of Unskilled Labour (A Study of Causes, Permanency and Assimilation in Nagpur), 2005.

[12] Lee E.S, “A Theory of Migration", Demography, vol. 3, 47-57, (1966).

[13] Mehta, B.C. and A. Kohli, "Spatial Mobility of Population: An Inter-District study of Rajasthan", Demography India, vol. 22(2), 247-266, (1993).

[14] P. Sainath, Everybody loves a Good Drought (Penguin Books, New Delhi, 1996).

[15] Selvaraj, K.G. and P.S.S. Rao, "Household MigrationUrbanization and Consequences", Demography India, vol. 22(2), 203-210, (1993).

\section{Volume 6 Issue 1, January 2017




\section{International Journal of Science and Research (IJSR) \\ ISSN (Online): 2319-7064}

Index Copernicus Value (2015): 78.96 | Impact Factor (2015): 6.391

[16] S. Rajakutty, SanthiAcharya and T. Haque, India Rural Development Report, Hyderabad: National Institute of Rural Development, 1999).

[17] Swaranjit Mehta-Migration: A Spatial Perspective (A case study of Bist Doab-Punjab), 2004 